\title{
The Diagnostic Value of Serum TgAb in the Tg-Negative and TgAb-Positive DTC Patients after Successful Ablation
}

\author{
Qun Fan'1, Xinhui Su', Anren Kuang2* \\ ${ }^{1}$ Department of Nuclear Medicine, Zhongshan Hospital, Xiamen University, Xiamen, China \\ ${ }^{2}$ Department of Nuclear Medicine, West China Hospital, Sichuan University, Chengdu, China \\ Email: ${ }^{\star}$ karenfanqun@126.com
}

How to cite this paper: Fan, Q., Su, X.H. and Kuang, A.R. (2016) The Diagnostic Value of Serum TgAb in the Tg-Negative and TgAb-Positive DTC Patients after Successful Ablation. Journal of Cancer Therapy, 7, 889-900.

http://dx.doi.org/10.4236/jct.2016.712086

Received: September 19, 2016

Accepted: November 6, 2016

Published: November 9, 2016

Copyright $\odot 2016$ by authors and Scientific Research Publishing Inc. This work is licensed under the Creative Commons Attribution International License (CC BY 4.0).

http://creativecommons.org/licenses/by/4.0/

\section{Abstract}

Objective: The aim of this retrospective study was to evaluate diagnostic accuracy of serum thyroglobulin antibody $(\mathrm{TgAb})$ in thyroglobulin $(\mathrm{Tg})$-negative and $\mathrm{TgAb}-$ positive $\left(\mathrm{Tg}^{-} \mathrm{TgAb}^{+}\right)$patients with differentiated thyroid carcinoma (DTC). Method: We studied 341 patients with histologically confirmed DTC who had undergone remnant ablation and showed $\mathrm{Tg}^{-} \mathrm{TgAb}^{+}$assessed by electrochemiluminescence immunoassay (ECLIA). The cases were divided into two groups, including recurrence group 119 cases and no evidence of disease (NED) group 222 cases. Receiver operating characteristic (ROC) curve analysis was carried out. The symmetric measures of the two diagnostic methods (the golden standard and the diagnostic standard as serum $\mathrm{TgAb}$ level alone) were analyzed using McNemar test and measure of agreement Kappa. Results: Serum TgAb level (1381.292 \pm 1017.221$) \mathrm{IU} / \mathrm{ml}$ of patients with recurrent group was significantly higher than that $(125.559 \pm 314.047) \mathrm{IU} / \mathrm{ml}$ of NED group $(\mathrm{P}=0.000<0.001)$. The area under the ROC curve was 0.962 and its asymptotic $95 \%$ confidence interval $(\mathrm{CI})$ was $(0.942,0.982)$ that was high statistical significance. The cut-off value of TgAb was determined and interpreted at $246.695 \mathrm{IU} / \mathrm{ml}$ with sensitivity (92.40\%) and specificity (92.30\%). McNemar test showed that the diagnostic results of the two methods were not significant difference $(\mathrm{P}=0.230>$ 0.05). Measure of agreement Kappa was $0.841, \mathrm{P}=0.000<0.001$ that showed the agreement of the two diagnostic methods was significant. Conclusion: Serum TgAb is a useful tumor marker for recurrence in Tg-negative and TgAb-positive DTC patients who underwent thyroidectomy and remnant ablation. The cut-off value of $\mathrm{TgAb}$ is $246.695 \mathrm{IU} / \mathrm{ml}$, that is to say, serum TgAb level upon $246.695 \mathrm{IU} / \mathrm{ml}$ may be associated with the persistence or recurrence of DTC. 


\section{Keywords}

DTC, TgAb, Cut-Off Value

\section{Introduction}

Serum thyroglobulin (Tg) level and ${ }^{131}$ I whole-body scanning (WBS) are the leading recognized sensitive and specific tools for the detection of recurrence or metastases during follow-up of thyroidectomized patients with differentiated thyroid carcinoma (DTC) who underwent remnant ablation. These have been widely accepted management protocols [1] [2]. However, the presence of serum anti-Tg antibody (TgAb) may interfere with $\mathrm{Tg}$ measurement made by immunometric assay (IMA) or radioimmunoassay (RIA) methods and cause false results [3] [4] [5] [6]. In the presence of $\mathrm{TgAb}$, IMA methods consistently underestimate serum Tg levels, while RIA methods generally overestimate serum TG levels [5] [6] [7]. Previous studies have showed the incidence of TgAb-positive $\left(\mathrm{TgAb}^{+}\right)$in DTC patients ranges from $10 \%$ to $30 \%$ [8] [9] [10] [11] [12] and about $20 \%-30 \%$ have been proven recurrence or metastasis among the $\mathrm{TgAb}^{+}$ DTC patients. TgAb currently compromises the use of serum $\mathrm{Tg}$ as a tumor marker in this kind of DTC patients. Also, TgAb has been studied extensively in order to evaluate its place in clinical practice [8]-[13]. Serum TgAb levels can be used as a marker for the studied patients that have been shown to be cost-effective in a few studies [8]-[17], but its possible diagnostic benefit remains controversial. And, it has not been confirmed the diagnostic significance of elevated serum TgAb levels with TG-undetectable and TgAbdetectable $\left(\mathrm{Tg}^{-} \mathrm{TgAb}^{+}\right)$DTC patients.

Therefore, the aims of the present study were to evaluate diagnostic accuracy of serum $\mathrm{TgAb}$ in $\mathrm{Tg}^{-} \mathrm{TgAb}^{+}$DTC patients who had previously received thyroidectomy and radioiodine ablation therapy and ascertain the cut-off value of $\operatorname{TgAb}$ to differentiate between the pathologic and disease-free patients.

\section{Materials and Methods}

\subsection{Patients}

We performed a retrospective review on medical records of 1236 patients with histologically confirmed DTC who were admitted to the Nuclear Medicine Department of Zhongshan Hospital Xiamen University from January 2001 to December 2014. All patients underwent total or subtotal thyroidectomy, followed by radioiodine remnant ablation completely and thyroid hormone suppression of thyroid-stimulating hormone (TSH).

According to the collecting and excluding standards, 341 patients entered the study finally. The patients were divided into the recurrence group $(\mathrm{n}=119)$ and no evidence of disease $(\mathrm{NED})$ group $(\mathrm{n}=222)$ on the basis of the golden standard.

\subsection{Definitions}

A serum TG level of below $1 \mu \mathrm{g} / \mathrm{L}$ with suppressed TSH levels or $2 \mu \mathrm{g} / \mathrm{L}$ with stimulated 
TSH levels was considered undetectable $\left(\mathrm{Tg}^{-}\right)$. We defined $\mathrm{TgAb}$-detectable $\left(\mathrm{TgAb}^{+}\right)$as upon $10 \mathrm{IU} / \mathrm{ml}$. Recurrence was defined as either a regional recurrence and/or distant spread.

The DTC patients with $\mathrm{Tg}^{-} \mathrm{TgAb}^{+}$and successful ablation of thyroid remnant enrolled the study. The DTC patients with TG-detectable, $\mathrm{TgAb}$-undetectable $\left(\mathrm{Tg}^{+} \mathrm{TgAb}^{-}\right)$or thyroid remnant in thyroid bed were excluded the study. The gold standard for the study was either the diagnosis of recurrence established by biopsy and/or the diagnosis of the routine clinical examinations (chest x-rays, CT scanning, neck high-resolution echography and radioiodine whole body scan).

Sensitivity (Sen) and specificity (Spe) were defined as true positive and true negative, respectively. Positive likelihood ratio $(+\mathrm{LR})$ was defined as the ratio of the true positive and false positive (Sen/1 - Spe). Youden Index $(\mathrm{YI})=$ Sen + Spe -1 . Pre-test probability is defined as the probability that a patient suffers from recurrence or metastases by means of his/her medical history and physical sign. Post-test probability is defined as the probability of recurrent disease in a patient with a certain test result of TgAb. Pretest odds $=$ pre-test probability $/(1-$ pre-test probability $)$. Post-test odds $=$ pre-test odds $\times(+\mathrm{LR})$. Post-test probability $=$ post-test odds $/(1+$ post-test odds $)$.

\subsection{Serum Tg and TgAb Assays}

Serum Tg level was determined by means of electrochemiluminescence immunoassay (ECLIA) method using a commercially available kit (Roche Diagnostics $\mathrm{GmbH}$ ), which has a measuring range of $0.100-1000 \mu \mathrm{g} / \mathrm{L}$. The intra- and interassay coefficient of variability $(\mathrm{CV})$ were $1.8 \%$ and $3.2 \%$, respectively.

Serum $\mathrm{TgAb}$ level was measured by means of ECLIA method (Roche Diagnostics $\mathrm{GmbH}$ ) with measurable range of $10-4000 \mathrm{IU} / \mathrm{ml}$. The intra- and interassay CV were $5.2 \%$ and $7.3 \%$, respectively.

\subsection{Statistical Analysis}

Data were expressed as mean \pm SD. Statistical analysis was done using Independent-samples $t$ test and the $\chi^{2}$ test. A P-value of less than 0.05 was considered to indicate a statistically significant difference.

The analysis of diagnostic value was performed by receiver operating characteristic (ROC) curve at the time of evaluation. The nonparametric method could be used to estimate the area under ROC curve. The area under the ROC curve (AUC) with $95 \%$ confidence interval (CI) was calculated to express the overall diagnostic accuracy of the test. The AUC, P value, and cutoff point were obtained from the curve. The cut-off value was defined as the threshold value of the maximum Youden Index (YI). Corresponding to Spe, Sen, PV and LR were calculated for the cut-off value in contingency tables.

The symmetric measures of the two diagnostic methods (the golden standard and the diagnostic standard as serum $\mathrm{TgAb}$ level alone)were analyzed using McNemar test and measure of agreement Kappa. And, the analysis of positive likelihood ratio (+LR) with 
different threshold values were carried out in the study.

Statistical analyses were performed with SPSS for Windows Software package (Release 17.0, SPSS Inc., US).

\section{Results}

\subsection{Serum TgAb Levels and Clinical Characteristics in the Two Groups}

A total of 341 patients were enrolled and divided into two groups: 119 patients with recurrence group and 222 patients with NED group between January 2001 and December 2014. Table 1 summarizes the clinical characteristics of 341 patients. Age, sex and histology of recurrence group were compared with those of NED group respectively; no significant differences were all found $(\mathrm{P}>0.05)$. Serum $\mathrm{TgAb}$ level was significantly higher in the patients with recurrence group in comparison with patients in NED group $(1381.292 \pm 1017.221$ vs. $125.559 \pm 314.047 \mathrm{IU} / \mathrm{ml}, \mathrm{P}=0.000<0.001)$. Medians of serum $\mathrm{TgAb}$ level were $1038.4000 \mathrm{IU} / \mathrm{ml}$ and $63.745 \mathrm{IU} / \mathrm{ml}$ in recurrence group and NED group, respectively.

Table 1. Characteristics of the study populations, according to study group.

\begin{tabular}{|c|c|c|}
\hline Characteristic & Recurrence Group & NED Group \\
\hline Patients-no. (\%) & $119(34.897)$ & $222(65.103)$ \\
\hline \multicolumn{3}{|l|}{ Sex-no. ${ }^{* \dagger \dagger}$} \\
\hline Female & 103 & 177 \\
\hline Male & 16 & 45 \\
\hline \multicolumn{3}{|l|}{ Age-years } \\
\hline Mean $\pm \mathrm{SD}^{\dagger \varsigma}$ & $47.64 \pm 11.96$ & $45.74 \pm 11.25$ \\
\hline Range & $16-82$ & $13-76$ \\
\hline \multicolumn{3}{|l|}{ Histology-no. ${ }^{\ddagger \dagger \dagger}$} \\
\hline Papillary & 79 & 172 \\
\hline Follicular & 25 & 34 \\
\hline Papillary/Follicular & 15 & 16 \\
\hline \multicolumn{3}{|c|}{ Serum TgAb level (IU/ml) } \\
\hline Mean $\pm \mathrm{SD}^{\S}$ & $1381.292 \pm 1017.221$ & $125.559 \pm 314.047$ \\
\hline Median & 1038.400 & 63.745 \\
\hline Range & $53.230-4000.000$ & $10.000-4000.000$ \\
\hline
\end{tabular}

${ }^{*}$ There was not statistically significant difference $\left(\chi^{2}=2.457, \mathrm{P}=0.117>0.05\right)$. ${ }^{\dagger}$ No significant difference was found $(\mathrm{t}=1.454, \mathrm{P}=0.147>0.05)$. ${ }^{\mathrm{*}}$ It was not statistically significant difference $\left(\chi^{2}=5.229, \mathrm{P}=0.073>0.05\right)$. 'Serum thyroglobulin autoantibodies $(\mathrm{TgAb})$ levels were significantly higher in the recurrence group as compared with that in the NED group $(t=13.135, P=0.000<0.001)$. ${ }^{~}$ Comparison of Recurrence Group vs. NED Group by Independent-Samples $\mathrm{T}$ Test. ${ }^{\dagger \dagger}$ Comparison of Recurrence Group vs. NED Group by $\chi^{2}$ test.

\subsection{Receiver Operating Characteristic Curve Analysis}

Figure 1 showed nonparametric ROC curve of serum $\operatorname{TgAb}$ levels of the studied patients. ROC curve analysis showed the AUC of 0.962 which was significantly different 


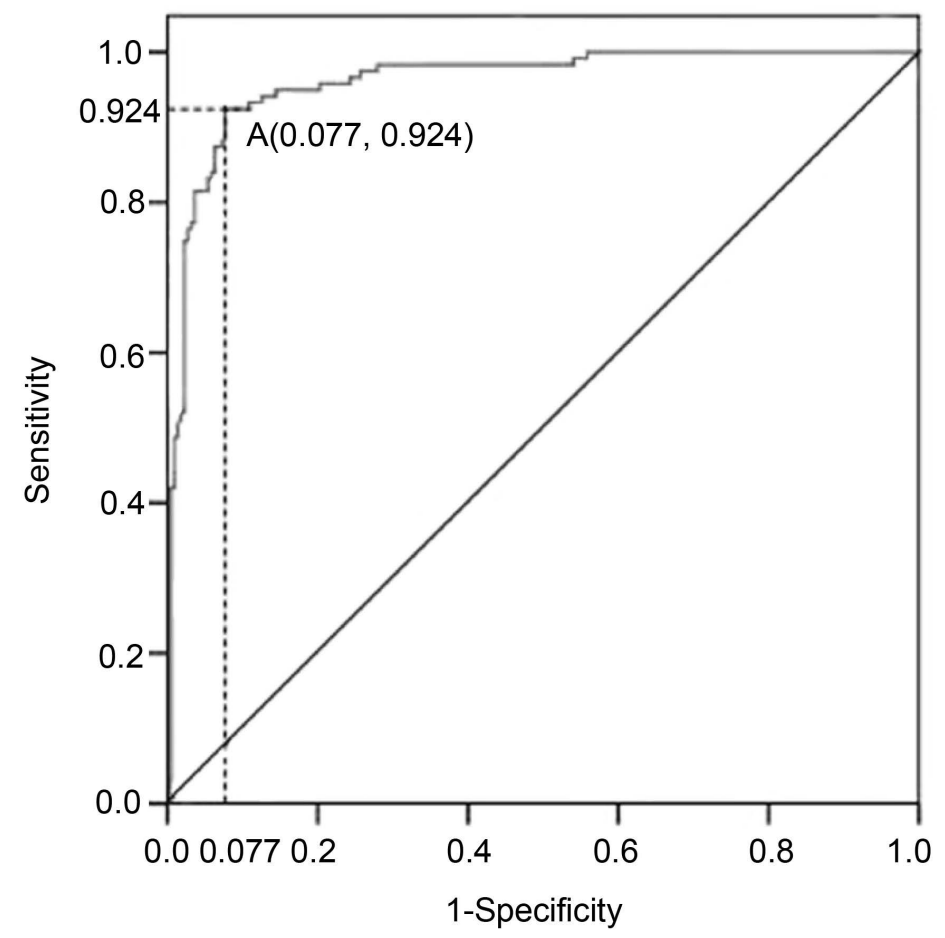

Figure 1. Nonparametric ROC curve of serum TgAb levels of the studied patients. The area under the curve (AUC) was 0.962 . The area was significantly different from $0.5(\mathrm{P}=0.000<0.001)$. Point $\mathrm{A}$ on the curve is the closest to the upper left corner. Its ordinate is 0.924 , its abscissa is 0.077. If point $\mathrm{A}$ is defined as optimal operating point, corresponding to Sen and Spe are $92.40 \%, 92.30 \%$, respectively.

from $0.5(\mathrm{P}=0.000<0.001)$. The $95 \% \mathrm{CI}$ for the area was $(0.942,0.982)$. The interval did not consist of 0.5.The results showed that serum $\mathrm{TgAb}$ level reflects the recurrence of DTC in $\mathrm{Tg}^{-} \mathrm{TgAb}^{+}$patients after thyroid ablation successfully. Point A on the curve is the closest to the upper left corner. Its ordinate is 0.924 , its abscissa is 0.077 . If point A is defined as optimal operating point, corresponding to Sen and Spe are $92.40 \%$, $92.30 \%$, respectively.

\subsection{Determining the Cut-Off Value}

YI is an index of analysis by synthesis that reflects the authenticity of diagnostic test. It is defined as (Sen + Spe -1$)$; its range is from -1 to +1 . As the analysis of definite quantity, the closer the value is to the upper limit $(+1)$, the higher the overall accuracy of the diagnostic test.

We selected the operating point on the ROC curve the closest to the upper left corner as cut-off point (point A showed Figure 1). Corresponding YI (0.847) is a maximum index. That is to say, the Sen/Spe pair maximizes the function [Sen - $(1-$ Spe) . Corresponding ordinate and abscissa are $0.924,0.077$ respectively (i.e., the predicted diagnostic Sen and Spe are 92.40\%, 92.30\% respectively). And, corresponding TgAb level is $246.695 \mathrm{IU} / \mathrm{ml}$ (point A showed Figure 2). 


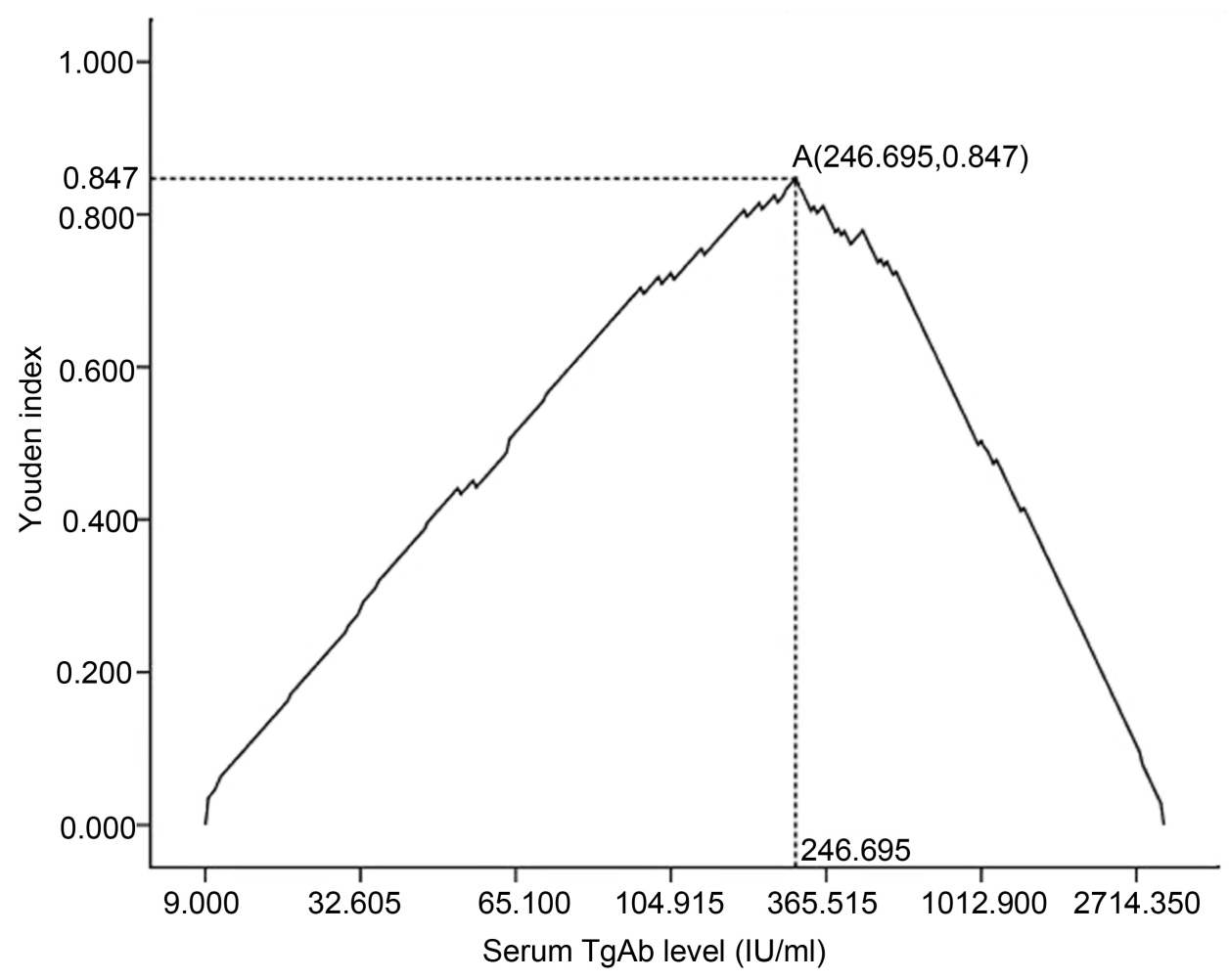

Figure 2. Line chart of Youden index by serum TgAb levels. The ordinate of point A on the curve is 0.847 (i.e., the maximum value of Youden index is 0.847 ), corresponding abscissa is 246.695 (i.e., serum TgAb level is $246.695 \mathrm{IU} / \mathrm{ml}$ ). That is to say, the cut-off value of serum $\mathrm{TgAb}$ is $246.695 \mathrm{IU} / \mathrm{ml}$.

\subsection{Symmetric Measures}

The symmetric measures of the two diagnostic methods (the golden standard and the diagnostic standard as serum TgAb level alone) were analyzed using McNemar test and measure of agreement Kappa. McNemar test showed that the diagnostic result of the two methods was not significant difference $(\mathrm{P}=0.230>0.05)$. Agreement Kappa $(\kappa)$ is a measurement of evaluating agreement of the diagnostic result of the two methods. Thus, $\kappa \geq 0.7$ is considered to be excellent test results (i.e., the agreement of two diagnostic methods was high statistical significance); $0.4 \leq \kappa<0.7$ is considered to be statistical significance; $\kappa<0.4$ is considered to be no statistical significance. Measure results of agreement Kappa was " $\kappa=0.841, \mathrm{P}=0.000<0.001$ ”, that showed the agreement of the two diagnostic methods was high statistical significance.

\subsection{Diagnostic Properties and Analysis of Positive Likelihood Ratio}

Selecting $\mathrm{TgAb}=246.695 \mathrm{IU} / \mathrm{ml}$ as cut-off value, we predicted the studied patients (Table 2). Diagnostic properties were expressed by Sen, Spe, positive likelihood ratio $(+\mathrm{LR})$, accuracy $(\mathrm{Acc})$, positive predictive value $(+\mathrm{PV})$ and negative predictive value $(-\mathrm{PV})$. According to Table 2, we calculated $+\mathrm{LR}=12.83[(110 / 119) /(16 / 222)]$, Acc $=$ 92.67\% $[(110+206) / 341],+\mathrm{PV}=87.30 \%(110 / 126),-\mathrm{PV}=95.81 \%(206 / 215)$. 
The analysis of $+\mathrm{LR}$ with different threshold values were calculated in the study (Table 3, Figure 3). Table 3 and Figure 3 showed that the higher serum TgAb level, the higher corresponding +LR was (i.e., the higher serum TgAb level, the more possible recurrence was). According to the relationship of pre-test odds, post-test odds, pre-test probability and post-test probability, we calculated the results as follows: when the pre-test probability fixed and except for the mixed function of other factors, the possibility of recurrence as $\mathrm{TgAb} \geq 246.695 \mathrm{IU} / \mathrm{ml}$ was 10.294 times that of $\mathrm{TgAb}<246.695$ $\mathrm{IU} / \mathrm{ml}$; the possibility of recurrence as $\mathrm{TgAb}>1000.000 \mathrm{IU} / \mathrm{ml}$ was 1.086 times that of $246.695 \mathrm{IU} / \mathrm{ml} \leq \mathrm{TgAb} \leq 1000.000 \mathrm{IU} / \mathrm{ml}, 4.571$ times that of $100.000 \mathrm{IU} / \mathrm{ml} \leq \mathrm{TgAb}<$

Table 2. Comparison of the two diagnostic results.

\begin{tabular}{cccc}
\hline & \multicolumn{2}{c}{ Clinical routine diagnostic methods (Golden standard) } & Total (n) \\
\cline { 2 - 3 } & Recurrence $(\mathrm{n})$ & No evidence of disease $(\mathrm{n})$ & \\
\hline $\mathrm{TgAb} \geq 246.695(\mathrm{n})$ & 110 & 16 & 126 \\
$\mathrm{TgAb}<246.695(\mathrm{n})$ & 9 & 206 & 215 \\
$\operatorname{Total}(\mathrm{n})$ & 119 & 222 & 341 \\
\hline
\end{tabular}

Table 3. Positive likelihood ratios of different threshold values.

\begin{tabular}{|c|c|c|c|c|c|}
\hline \multirow{2}{*}{$\operatorname{TgAb}(\mathrm{IU} / \mathrm{ml})$} & \multicolumn{2}{|c|}{ Recurrence group } & \multicolumn{2}{|c|}{ NED group } & \multirow{2}{*}{$+\mathrm{LR}$} \\
\hline & $\mathrm{n}$ & Ratio & $\mathrm{n}$ & Ratio & \\
\hline$\geq 1000.000$ & 62 & $62 / 119=0.521$ & 5 & $5 / 222=0.023$ & $0.521 / 0.023=22.652$ \\
\hline $\begin{array}{c}246.695 \leq \mathrm{TgAb}< \\
1000.000\end{array}$ & 48 & $48 / 119=0.403$ & 12 & $12 / 222=0.054$ & $0.403 / 0.054=7.463$ \\
\hline $\begin{array}{c}100.000 \leq \mathrm{TgAb}< \\
246.695\end{array}$ & 6 & $6 / 119=0.050$ & 42 & $42 / 222=0.189$ & $0.050 / 0.189=0.265$ \\
\hline $\begin{array}{c}10.000 \leq \mathrm{TgAb}< \\
100.000\end{array}$ & 3 & $3 / 119=0.025$ & 163 & $163 / 222=0.734$ & $0.025 / 0.734=0.034$ \\
\hline Total & 119 & 1 & 222 & 1 & \\
\hline
\end{tabular}

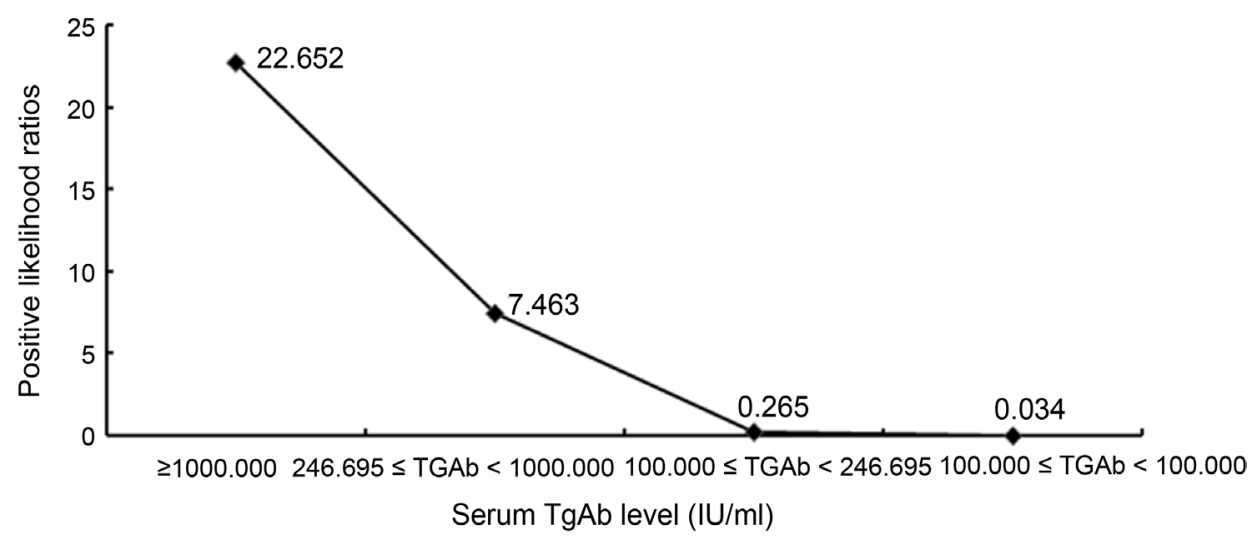

Figure 3. Positive likelihood ratio of different threshold value of serum $\operatorname{TgAb}$. The serum $\operatorname{TgAb}$ levels were higher; the corresponding $+\mathrm{LR}$ was higher. That is to say, the higher serum $\operatorname{TgAb}$ levels, the more possible recurrence or metastases was. 
$246.695 \mathrm{IU} / \mathrm{ml}, 29.109$ times that of $10.000 \mathrm{IU} / \mathrm{ml} \leq \mathrm{TgAb}<100.000 \mathrm{IU} / \mathrm{ml}$; the possibility of recurrence as $246.695 \mathrm{IU} / \mathrm{ml} \leq \mathrm{TgAb} \leq 1000.000 \mathrm{IU} / \mathrm{ml}$ was 4.209 times that of $100.000 \mathrm{IU} / \mathrm{ml} \leq \mathrm{TgAb}<246.695 \mathrm{IU} / \mathrm{ml}, 26.802$ times that of $10.000 \mathrm{IU} / \mathrm{ml} \leq \mathrm{TgAb}<$ $100.000 \mathrm{IU} / \mathrm{ml}$; the possibility of recurrence as $100.000 \mathrm{IU} / \mathrm{ml} \leq \mathrm{TgAb}<246.695 \mathrm{IU} / \mathrm{ml}$ was 6.368 times that of $10.000 \mathrm{IU} / \mathrm{ml} \leq \mathrm{TgAb}<100.000 \mathrm{IU} / \mathrm{ml}$.

According to the analysis of positive likelihood ratio, we assumed that the possibility of recurrence/metastases as $246.695 \mathrm{IU} / \mathrm{ml} \leq \mathrm{TgAb}<1000.000 \mathrm{IU} / \mathrm{ml}$ is 10 units, the possibility of recurrence/metastases as TgAb $>1000.000 \mathrm{IU} / \mathrm{ml}, 100.000 \mathrm{IU} / \mathrm{ml} \leq \mathrm{TgAb}$ $<246.695 \mathrm{IU} / \mathrm{ml}$ and $10.000 \mathrm{IU} / \mathrm{ml} \leq \mathrm{TgAb}<100.000 \mathrm{IU} / \mathrm{ml}$ is 10.860 units, 2.376 units, 0.373 units respectively (Figure 4).

\section{Discussion}

Self antigen of TgAb is TG. And, TG is incomplete "inaccessible antigen" and giant molecule glycoprotein synthesized by thyroid follicular epithelial cell. Serum TgAb is usually of IgG1, IgG3 or IgG4 subtypes in DTC patients [18]. Serum TG is an established tumor marker in monitoring recurrence patients with DTC [19], but TgAb interference affects serum $\mathrm{Tg}$ measurement. Therefore, we should attach importance to the $\mathrm{TgAb}$ interference in serum $\mathrm{Tg}$ measurement for $\mathrm{Tg}^{-} \mathrm{TgAb}^{+}$DTC patients. Some studies [10]-[15] [20] [21] reported elevated TgAb level may be representative of recurrence in $\mathrm{Tg}^{-} \mathrm{TgAb}^{+}$DTC patients. That is, these kinds of patients were additionally diagnosed as recurrent or metastatic disease by measuring their serum $\mathrm{TgAb}$ levels. Some studies [22] [23] [24] [25] reported that production of TgAb is mainly due to intrathyroidal and extrathyroidal lymphocytes for antigen presentation to immune cells. Only rarely $\mathrm{TgAb}$ is produced by circulating lymphocytes and immune cells in cervical lymph nodes and bone marrow. This notion shows that the production of thyroid antibodies depends on antigenic components. After successful ablation of thyroid remnant tissue, the main source of $\operatorname{TgAb}$ is extrathyroidal lymphocytes. That is to say,

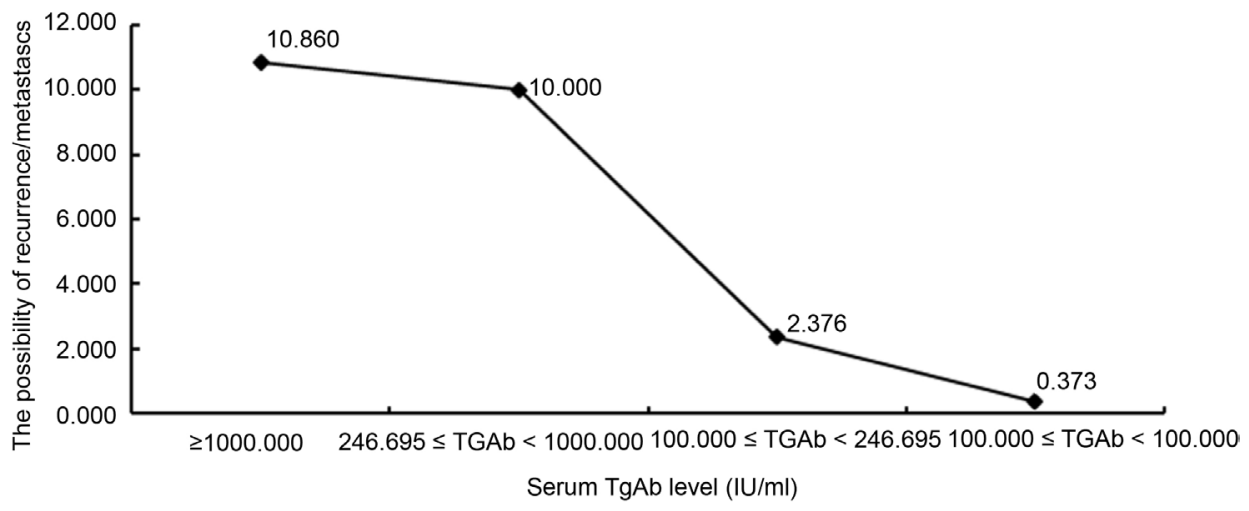

Figure 4. The possibility of recurrence/metastases as different threshold values of serum $\mathrm{TgAb}$ levels. Assuming the possibility of recurrence/metastases as $246.695 \mathrm{IU} / \mathrm{ml} \leq \mathrm{TgAb}<1000.000$ $\mathrm{IU} / \mathrm{ml}$ is 10 units, the possibility of recurrence/metastases as TgAb $>1000.000 \mathrm{IU} / \mathrm{ml}, 100.000$ $\mathrm{IU} / \mathrm{ml} \leq \mathrm{TgAb}<246.695 \mathrm{IU} / \mathrm{ml}$ and $10.000 \mathrm{IU} / \mathrm{ml} \leq \mathrm{TgAb}<100.000 \mathrm{IU} / \mathrm{ml}$ is $10.860 \mathrm{units}, 2.376$ units, 0.373 units respectively. 
persistent tumors mainly become source of antigenic components of producing $\operatorname{TgAb}$. The notion theoretically explains that serum $\mathrm{TgAb}$ level is an index of recurrence or metastases in $\mathrm{Tg}^{-} \mathrm{TgAb}^{+}$DTC patients of complete ablation.

In this study, we analyzed the diagnostic accuracy and ascertained the cut-off value of serum $\mathrm{TgAb}$ in the enrolled patients by means of ROC curve and $+\mathrm{LR}$ analysis of different threshold values. Serum TgAb levels (1381.292 \pm 1017.221) IU/ml of patients with recurrence group was significantly higher than those $(125.559 \pm 314.047) \mathrm{IU} / \mathrm{ml}$ of NED group $(P=0.000)$ (Table 1$)$, suggesting that serum TgAb level might be related to the persistence DTC. Similar findings have been reported previously [11] [15]. Hjiyiannakis et al. [10] reported that 9 patients (22.5\%) had shown progressively increasing $\mathrm{TgAb}$ levels and been confirmed recurrence diseases among 40 DTC patients with $\mathrm{TG}^{-} \mathrm{TgAb}^{+}$. The result showed serum $\mathrm{TgAb}$ can indicate active tumor. Research results of most scholars [8] [9] [10] [11] [12] [15] showed that the retention of elevated $\mathrm{TgAb}$ levels appeared to act as "tumor marker" in the DTC patients with $\mathrm{TG}^{-} \mathrm{TgAb}^{+}$. These notions provide practically reasons. But, it is controversial what its cut-off value of serum $\mathrm{TgAb}$ is. Only according to their clinical experience, most scholars [10] [11] [15] acted "TgAb $=100 \mathrm{U} / \mathrm{ml}, \mathrm{TgAb}$ titre $=1 / 100, \mathrm{TgAb}=50 \mathrm{U} / \mathrm{ml}$ " as referential value that was not been statistically analyzed by diagnostic test.

According to our knowledge, this is the rare report on the application of ROC curve and +LR with different threshold values analyses in order to evaluate the diagnostic value of serum $\mathrm{TgAb}$ monitoring in the follow-up after successful ablation remnant thyroid tissue for TG-undetectable ( $\mathrm{TG}^{-}$) DTC patients. ROC curve is applied to evaluate the accuracy of diagnostic test. ROC curve occupy a central or unifying position in the process of assessing and using diagnostic tools. The ROC curve depicts the overlap between the two distributions by plotting the Sen vs. $(1-\mathrm{Spe})$ for the complete range of decision thresholds. The y-axis is Sen, and the $\mathrm{x}$-axis is (1-Spe). The ROC graph is a plot of all of the Sen/Spe pairs resulting from continuously varying the decision threshold over the entire range of results observed. Every point on the curve represents a Sen/Spe pair corresponding to a particular decision threshold [26].

AUC is a measure of predicted accuracy. The results of our ROC study showed that AUC value was 0.956 (Figure 1). There was statistical difference between the AUC (0.956) and $A_{z}(0.5)$. And the AUC value (0.956) was higher than 0.9. The results showed that the diagnostic test was higher accuracy. That is to say, it was important diagnostic significance for serum $\operatorname{TgAb}$ level to evaluate recurrence in DTC patients of $\mathrm{TG}^{-} \mathrm{TgAb}^{+}$. Even, it may be possible that $\mathrm{TgAb}$ is more likely to act as a tumor marker in these patients.

It showed that $\mathrm{TgAb}$ at a single cut-off level was used with regard to monitoring the recurrence of the DTC patients with $\mathrm{TG}^{-} \mathrm{TgAb}^{+}$received successful ablation. As showed in Figure 1 and Figure 2, we selected the "A" point of the closet to the upper left corner on the curve as cut-off point. Corresponding to $\mathrm{YI}$ is the maximum value ( $\mathrm{YI}=0.847$ ). ROC analysis showed that the cut-off point $(\mathrm{TgAb}=246.695 \mathrm{IU} / \mathrm{ml})$ was the higher Sen (92.40\%) and Spe (92.30\%). And this may reflect the fact that 110 of 119 of the patients 
with recurrence had increased $\mathrm{TgAb}$ level ( $\geq 246.695 \mathrm{IU} / \mathrm{ml}$ ) (Table 2). Only 7.56\% (9/119) patients with recurrence were falsely classified as NED when the cut-off value revealed by ROC analysis was used (Table 2).

In the present study, the analytical results of $+\mathrm{LR}$ with different threshold values showed that the higher serum $\mathrm{TgAb}$ level, the more possible recurrence is (Table 3). The symmetric measures of the two diagnostic methods (the golden standard and the diagnostic standard as serum $\operatorname{TgAb}$ level alone) were carried out by use of McNemar test and measure of agreement Kappa. McNemar test estimated of the DTC recurrence for studied patients with acting " $\mathrm{TgAb}=246.695 \mathrm{IU} / \mathrm{ml}$ " as cut-off value predicting results was compared with that for studied patients with clinical routine diagnostic methods predicting results. Statistically significant difference was not found $(\mathrm{P}=0.230>$ 0.05). Aside, measure of agreement Kappa shown that the two diagnostic methods is excellent symmetry $(\kappa=0.841>0.7, \mathrm{P}=0.000<0.05)$. The statistical results shown that it was high diagnostic value for predicting the studied patients with acting " $\mathrm{TgAb}=$ $246.695 \mathrm{IU} / \mathrm{ml}$ ” as cut-off value. Serum TgAb level upon " $246.695 \mathrm{IU} / \mathrm{ml}$ ” may be associated with recurrent diseases.

Hjiyiannakis et al. [12] carried out a retrospective review to investigate the recurrence or metastases in patients with $\mathrm{TgAb}^{+}$in the Royal Marsden Hospital. They reported that 11 patients were found recurrence among 28 patients of high titre group ( $\mathrm{TgAb}>1 / 100)$; only 2 patients were found recurrence among 12 patients of low titre group $(\mathrm{TgAb}<1 / 100)$. Median of $\mathrm{TgAb}$ level was $1 / 604$ in the high titre group, whereas it was $80 \mathrm{IU} / \mathrm{ml}$ in the low tire group. In our study, median of TgAb level was 1038.400 $\mathrm{IU} / \mathrm{ml}$ in the recurrence group, and is similar to the observations of Hjiyiannakis et al. [12]. Our study shown that median of TgAb level only was $63.745 \mathrm{IU} / \mathrm{ml}$ in the NED group. Compared with the reported result by Hjiyiannakis et al. [12], it was lower. In our study, serum TgAb levels were $(1381.292 \pm 1017.221) \mathrm{IU} / \mathrm{ml}$ in recurrence patients and $(125.559 \pm 314.047) \mathrm{IU} / \mathrm{ml}$ in NED patients. Compared with the observed results of Chung et al. [14], the serum TgAb levels were similar in recurrence group and lower in NED group. This phenomenon is likely to be owing to the presence for following factors, such as selected patients, sample, different assay methods of serum $\operatorname{TgAb}$ and a $\mathrm{TG} / \mathrm{TgAb}$ immune complex from the blood.

\section{Conclusions}

Serum TgAb is acted as a "tumor marker" and its cut-off value is $246.695 \mathrm{IU} / \mathrm{ml}$ in $\mathrm{TG}^{-} \mathrm{TgAb}^{+}$DTC patients with successful ablation of remnant thyroid tissue. The higher serum TgAb level, the more possible recurrence is. During the long follow-up of such patients populations, serum $\mathrm{TgAb}$ level should be routinely measured. As serum " $\mathrm{TgAb}$ $\geq 246.695 \mathrm{IU} / \mathrm{ml}$ ", correlative clinical measures should be carried out in order to find recurrence earlier and treating as soon as possible; as serum "TgAb $<246.695 \mathrm{IU} / \mathrm{ml}$ ", we should termly monitor the serum level of $\mathrm{TgAb}$.

We need carry out a research of big sample and a long-term clinical observation to nail down the diagnostic value of serum $\mathrm{TgAb}$ in patients with DTC. 


\section{Acknowledgements}

This study was supported by a grant from the National Natural Science Foundation of China (NSFC) (81071182).

\section{References}

[1] Schlumberger, M.J. (1999) Diagnostic Follow-Up of Well-Differentiated Thyroid Carcinoma: Historical Perspective and Current Status. Journal of Endocrinological Investigation, 22, 3-7.

[2] Mazzaferri, E.L. and Kloos, R.T. (2000) Using Recombinant Human TSH in the Management of Well-Differentiated Thyroid Cancer: Current Strategies and Future Directions. Thyroid, 10, 767-768. http://dx.doi.org/10.1089/thy.2000.10.767

[3] Baloch, Z., Carayon, P., Conte-Devolx, B., et al. (2003) Laboratory Medicine Practice Guidelines: Laboratory Support for the Diagnosis and Monitoring of Thyroid Disease. Thyroid, 13, 3-126. http://dx.doi.org/10.1089/105072503321086962

[4] Schneider, A.B. and Pervos, R. (1978) Radioimmunoassay of Human Thyroglobulin: Effect of Antithyroglobulin Antoantibodies. The Journal of Clinical Endocrinology \& Metabolism, 47, 126-137. http://dx.doi.org/10.1210/jcem-47-1-126

[5] Spencer, C.A. (2004) Challenges of Serum Thyroglobulin (Tg) Measurement in the Presence of Tg Autoantibodies. The Journal of Clinical Endocrinology \& Metabolism, 89, 37023704. http://dx.doi.org/10.1210/jc.2004-0986

[6] Locsei, Z., Szabolcs, I., Rácz, K., Kovács, G.L., Horváth, D. and Toldy, E. (2012) Serum Thyroglobulin Antibody Levels within or Near to the Reference Range May Interfere with Thyroglobulin Measurement. Biochemica Medica, 22, 365-370. http://dx.doi.org/10.11613/BM.2012.038

[7] Spencer, C., Petrovic, I. and Fatemi, S. (2011) Current Thyroglobulin Autoantibody (TgAb) Assays Often Fail to Detect Interfering TgAb That Can Result in the Reporting of Falsely Low/Undetectable Serum Tg IMA Values for Patients with Differentiated Thyroid Cancer. The Journal of Clinical Endocrinology \& Metabolism, 96, 1283-1291. http://dx.doi.org/10.1210/jc.2010-2762

[8] Pacini, F., Mariotti, S., Formica, N., et al. (1988) Thyroid Autoantibodies in Thyroid Cancer: Incidence and Relationship with Tumour Outcome. Acta Endocrinologica, 119, 373380. http://dx.doi.org/10.1530/acta.0.1190373

[9] Rubello, D., Girelli, M.E., Casara, D., et al. (1990) Usefulness of the Combined Antithyroglobulin Antibodies and Thyroglobulin Assay in the Follow-Up of Patients with Differentiated Thyroid Cancer. Journal of Endocrinological Investigation, 13, 737-742. http://dx.doi.org/10.1007/BF03349612

[10] Kumar, A., Shah, D.H., Shrihari, U., et al. (1994) Significance of Antithyroglobulin Autoantibodies in Differentiated Thyroid Carcinoma. Thyroid, 4, 199-202.

http://dx.doi.org/10.1089/thy.1994.4.199

[11] Spencer, C.A., Takeuchi, M., Kazarosyan, M., et al. (1998) Serum Thyroglobulin Autoantibodies: Prevalence, Influence on Serum Thyroglobulin Measurement, and Prognostic Significance in Patients with Differentiated Thyroid Carcinoma. The Journal of Clinical Endocrinology \& Metabolism, 83, 1121-1127.

[12] Hjiyiannakis, P., Mundy, J. and Harmer, C. (1999) Thyroglobulin Antibodies in Differentiated Thyroid Cancer. Clinical Oncology, 11, 240-244.

http://dx.doi.org/10.1053/clon.1999.9056 
[13] Gorges, R., Maniecki, M., Jentzen, W., Sheu, S.N., Mann, K., Bockisch, A., et al. (2005) Development and Clinical Impact of Thyroglobulin Antibodies in Patients with Differentiated Thyroid Carcinoma during the First 3 Years after Thyroidectomy. European Journal of Endocrinology, 153, 49-55. http://dx.doi.org/10.1530/eje.1.01940

[14] Chung, J.K., Park, Y.J., Kim, T.Y., et al. (2002) Clinical Significance of Elevated Level of Serum Antithyroglobulin Antibody in Patients with Differentiated Thyroid Cancer after Thyroid Ablation. Clinical Endocrinology, 57, 215-221. http://dx.doi.org/10.1046/j.1365-2265.2002.01592.x

[15] Kucuk, O.N., Aras, G., Kulak, H.A., et al. (2006) Clinical Importance of Anti-Thyroglobulin Auto-Antibodies in Patients with Differentiated Thyroid Carcinoma: Comparison with 99mTc-MIBI Scans. Nuclear Medicine Communications, 27, 873-876. http://dx.doi.org/10.1097/01.mnm.0000243376.49378.27

[16] Spencer, C.A., Bergoglio, L.M., Kazarosyan, M., Fatemi, S. and Lopresti, J.S. (2005) Clinical Impact of Thyroglobulin (Tg) and Tg Autoantibody Method Differences on the Management of Patients with Differentiated Thyroid Carcinomas. Journal of Clinical Endocrinology and Metabolism, 90, 5566-5575. http://dx.doi.org/10.1210/jc.2005-0671

[17] Spencer, C.A. (2011) Clinical Review: Clinical Utility of Thyroglobulin Antibody (TgAb) Measurements for Patients with Differentiated Thyroid Cancers (DTC). Journal of Clinical Endocrinology and Metabolism, 96, 3615-3627. http://dx.doi.org/10.1210/jc.2011-1740

[18] Caturegli, P., Kuppers, R.C., Mariotti, S., et al. (1994) IgG Subclass Distribution of Thyroglobulin Antibodies in Patients with Thyroid Disease. Clinical \& Experimental Immunology, 98, 464-469. http://dx.doi.org/10.1111/j.1365-2249.1994.tb05514.x

[19] Lubin, E., Mechlis-Frish, S., Zatz, S., et al. (1994) Serum Thyroglobulin and Iodine-131 Whole Body Scan in the Diagnosis and Assessment of Treatment for Metastatic Differentiated Thyroid Cancer. Journal of Nuclear Medicine, 35, 257-262.

[20] Kim, E.S., Lim, D.J., Baek, K.H., Lee, J.M., Kim, M.K., Kwon, H.S., et al. (2010) Thyroglobulin Antibody Is Associated with Increased Cancer Risk in Thyroid Nodules. Thyroid, 20, 885-891. http://dx.doi.org/10.1089/thy.2009.0384

[21] Rubello, D., Casara, D., Girelli, M.E., et al. (1992) Clinical Meaning of Circulating Antithyroglobulin Antibodies in Differentiated Thyroid Cancer: A Prospective Study. Journal of Nuclear Medicine, 33, 1478-1480.

[22] Chiovato, L., Latrofa, F., Braverman, L.E., et al. (2003) Disappearance of Humoral Thyroid Autoimmunity after Complete Removal of Thyroid Antigens. Annals of Internal Medicine, 139, 346-351. http://dx.doi.org/10.7326/0003-4819-139-5_Part_1-200309020-00010

[23] Weetman, A.P. and McGregor, A.M. (1994) Autoimmune Thyroid Disease: Further Developments in Our Understanding. Endocrine Reviews, 15, 788-830. http://dx.doi.org/10.1210/edrv-15-6-788

[24] Mariotti, S., del Prete, G.F., Maggi, E., et al. (1984) Surface Markers and Function of Circulating Thyroid Autoantibody-Producing Cells. The Journal of Clinical Endocrinology \& Metabolism, 58, 18-24. http://dx.doi.org/10.1210/jcem-58-1-18

[25] Chiovato, L., Latrofa, F., Braverman, L.E., Pacini, F., Capezzone, M., Masserini, L., et al. (2003) Disappearance of Humoral Thyroid Autoimmunity after Complete Removal of Thyroid Antigens. Annals of Internal Medicine, 139, 346-351. http://dx.doi.org/10.7326/0003-4819-139-5_Part_1-200309020-00010

[26] Zweig, M.H. and Campbell, G. (1993) Receiver-Operating Characteristic (ROC) Plots: A Fundamental Evaluation Tool in Clinical Medicine. Clinical Chemistry, 39, 561-577. 
Submit or recommend next manuscript to SCIRP and we will provide best service for you:

Accepting pre-submission inquiries through Email, Facebook, LinkedIn, Twitter, etc. A wide selection of journals (inclusive of 9 subjects, more than 200 journals)

Providing 24-hour high-quality service

User-friendly online submission system

Fair and swift peer-review system

Efficient typesetting and proofreading procedure

Display of the result of downloads and visits, as well as the number of cited articles

Maximum dissemination of your research work

Submit your manuscript at: http://papersubmission.scirp.org/

Or contact jct@scirp.org 